\title{
Pharmacognostical, Phytochemical studies and Antibacterial activity of Wood from Talipariti elatum Sw. (Fryxell) in Cuba
}

\author{
José González ${ }^{*}$, Armando Cuéllar², Silvia C. Morales ${ }^{3}$, Max Monan $^{4}$ \\ ${ }^{1,2}$ Department of Pharmacy, Faculty of Pharmacy and Foods, Havana University, Cuba \\ ${ }^{3}$ Department of Foods, Faculty of Pharmacy and Foods, Havana University, Cuba \\ ${ }^{4}$ ARVARNAM, Martinica, France
}

\begin{abstract}
A preliminary pharmacognostical and phytochemical evaluation of Talipariti elatum (Sw.) that grows in Cubawas realized to determine the macromorphology and micromorphology characteristics, the physicochemical and phytochemical parameters from the wood of this spice that grows in Cuba. This crude drug showed the characteristic physicochemical values such as moisture content (7.6\%), total ashes (1.14\%), water soluble ashes (0.19\%), acid insoluble ashes $(0.33 \%)$ and extractable matter in ethanol at $70 \%$ (10.87\%). Phytochemical screening revealed the possible presence of triterpenes and/or steroids, reductants sugars, tannins and/or phenolic compounds, flavonoids and bitter and astringent principles, realized under WHO parameters. The antibacterial activity of ethanolic extracts at 30,50 and $70 \%$ of the wood against Salmonella tiphymurium 14028, Bacillus cereus 11778, Escherichia coli 25922 and Staphylococcus aureus 25923 showed varying degrees of inhibition on the tested organisms.
\end{abstract}

Keywords—Talipariti elatum, wood, pharmacognostical, phytochemical, antibacterial.

\section{INTRODUCTION}

The Talipariti elatum tree is quite attractive with its straight trunk, broad green leaves and hibiscus-like flowers (Fig.1). It grows quite rapidly, often attaining 20 meters (66 ft.) or more in height. The attractive flower changes color as it matures, going from bright yellow to orange red and finally to crimson. Endemic to West Indies; native to Cuba and Jamaica; cultivated in Hispaniola, Puerto Rico, Virgin Islands (Virgin Gorda), and Lesser Antilles (Dominica, Guadeloupe, Martinique, St. Lucia).The name mahoe is derived from a Carib word. The 'blue' refers to blue-green streaks in the polished wood, giving it a distinctive appearance (Acevedo-Rodríguez and Strong, 2012; U.S. Department of Agriculture, 2013; Missouri Botanical Garden, 2013). In wetter areas it will grow in a wide range of elevations, up to 1,200 meters (3,900 ft.) and is often used in reforestation. It is the national tree of Jamaica (U.S Department of Agriculture, 2009).

It is an excellent wood with a rich variety of colors and attractive grain, but surprisingly, very little mahoe is currently being produced anywhere else. Mahoe can vary greatly in color from tree to tree; the blue tone does not tend to endure for many years. The wood transforms over time to shades of browns, purples, greys, and bluesy-greens (Tropic Ventures Rainforest Enrichment and Sustainable Forestry Project, 2009).

Since 2007, Areces and Fryxell renamed the Blue Mahoe (from Hibiscus elatus Sw. to Talipariti elatum Sw.) due to their arborescent behavior, prominent stipules that close the terminal yams, foliar lameness coriaceous, entire margin and a relative higher chromosomal number ( $2 \mathrm{n}=$ ca. 80,90 , ca. 92, ca. 96 and 120) (Fryxell, 2001). The same procedure was done with Hibiscus tiliaceus L (now Talipariti tiliaceum L.). Both species belongs to Malvaceae family.

The present study aimed at investigating the macromorphology, pharmacognostic evaluation and phytochemical screening of the wood of T. elatum Sw. towards standardization and monograph development and to evaluate the antibacterial activity of an ethanolic extract of this part of the tree. 


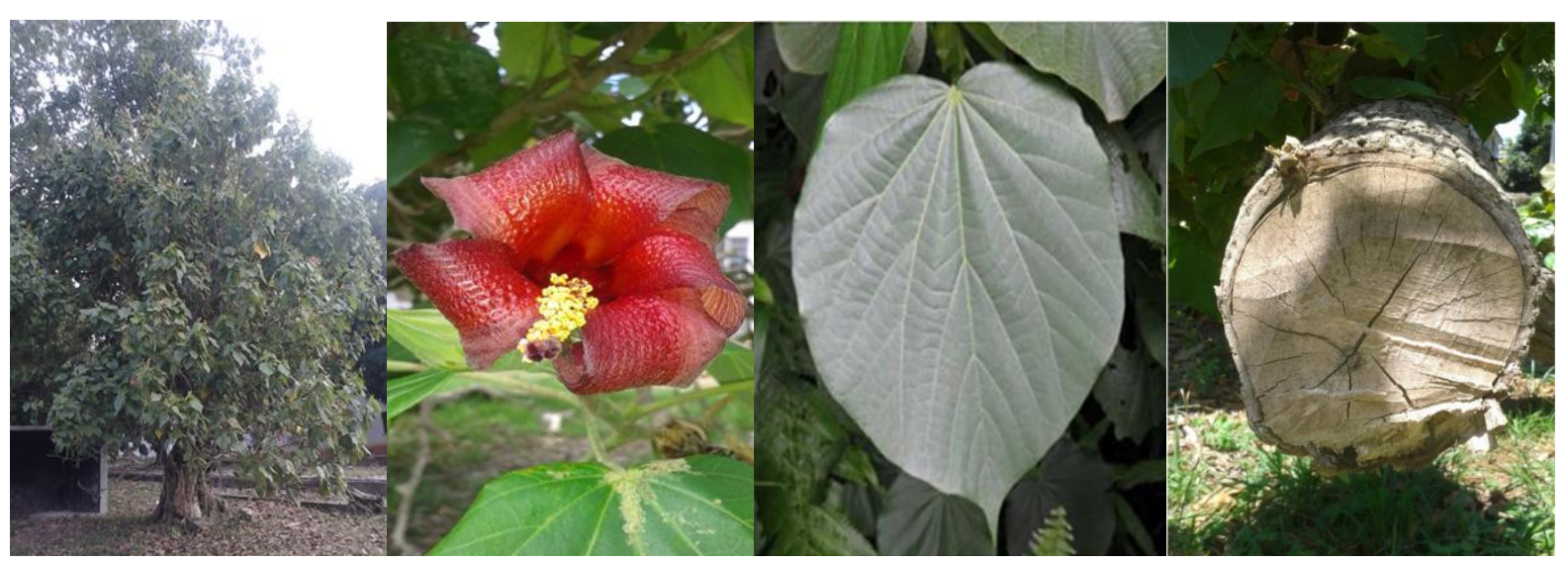

FIG. 1. TREE, FLOWER, LEAF AND WOOD OF TALIPARITI ELATUM (SW.)

\section{MATERIAL AND METHODS}

\subsection{Plant Material}

The wood was collected in January 2016 in the gardens of the Faculty of Pharmacy and Foods at Havana University, and identified at the herbarium of National Botany Garden of Havana, where the voucher specimen no. HAJB 82587 has been deposited. Specimen is registered as Talipariti elatum Sw. (Fryxell) Malvaceae (Sin. Hibiscus elatus Sw).

\subsection{Chemicals}

Analytical grade ethanol (Merck), analytical grade acetic acid (Merck), analytical grade n-butanol (Merck) and analytical grade methanol (Merck) were used in the analysis work. HPLC MeOH, Ultrapure MilliQ water and HPLC EtOH were purchase from BDH (Darmstadt, Germany). All solvents were degassing previously before used in an ultrasonic bath without filtration.

\subsection{Extract and Samples Preparation}

The wood was dried in an oven with controlled temperature, at $40^{\circ} \mathrm{C}$, during 5 days. The extracts were prepared with the ground material $(60 \mathrm{~g})$ without screen extracted in a Soxhlet apparatus with $675 \mathrm{~mL}$ of ethanol at $95 \%$ during 20 hours. The ethanolic extracts were concentrated and evaporated under vacuum to $200 \mathrm{~mL}$ at $120 \mathrm{rpm}$, a temperature of $70^{\circ} \mathrm{C}$ and 500 mbar.

\subsection{Phytochemical Studies}

Dried wood was ground to a coarse powder (grain size: $850 \pm 29 \mu \mathrm{m}$ ) and packed in a suitable container for phytochemical identification. The powder was extracted with $70 \%$ ethanol, filtered and concentrated using vacuum distillation.

The chemical constituents were screened according to Chhabra et al., 1989 to ascertain the presence of chemical components in diethyl ether, etanol and water. The UV spectrometric experiments were carried out on a UV-VIS JASCO V-530 (Japan). The scan range was 200 to $400 \mathrm{~nm}$; absorbance 0.000-3.0000, band width $2.0 \mathrm{~nm}$,spectral resolution $0.1 \mathrm{~nm}$ and the analyzed samples were diluted in methanol, into quartz cuvettes $(\mathrm{d}=1 \mathrm{~cm})$.

TLC conditions: TLCP (thin-layer chromatography plate) on silica gel with fluorescent indicator $254 \mathrm{~nm}$ on aluminum cards (layer thickness $0.2 \mathrm{~mm})(10 \times 20 \mathrm{~cm})$ using n-butanol: acetic acid: water (BAW 65:25:10) as developing agent $(\mathrm{v} / \mathrm{v} / \mathrm{v})$, concentrated sulfuric acid plus heat, $\mathrm{FeCl}_{3}$ and $\mathrm{AlCl}_{3}$ were the chromogenic agents. Rutin (R), quercetin (Q) and gossypitrin (G) were used as standard. The TLCP were examined under ultraviolet $(254 \mathrm{~nm}$ and $365 \mathrm{~nm}$ ) and ordinary light.

The total ash, acid insoluble ash, water soluble ash, extractable matter and moisture content were determined according to the standard procedures mentioned in the general rule of WHO, 1998.

\subsection{Procedures, Instrumentation and Parameters}

Chromatographic profile of ethanolic extract at $70 \%$ was carried out in an HPLC equipment Knauer-Azura (Germany) with UV detector at $280 \mathrm{~nm}$, flow $1 \mathrm{~mL} / \mathrm{min}$, with chromatographic column RP-18e (Knauer 250 x 4,6 mm Lichrospher 100-5), injecting 50,00 $\mu \mathrm{L}$ of the sample twice, during $60 \mathrm{~min}$, pump pressure at $11,7 \mathrm{MPa}$, using as eluent $(\mathrm{A}) \mathrm{H}_{2} \mathrm{O}$ and eluent (B) 
$\mathrm{MeOH}$. A gradient of $15-85 \% \mathrm{~B}$ during $30 \mathrm{~min}$ at $1 \mathrm{~mL} / \mathrm{min}$ followed by holding the gradient, increasing up to $50 \%$ A during $10 \mathrm{~min}$ and reversing to $0 \% \mathrm{~B}$ during $5 \mathrm{~min}$ and equilibrating during $5 \mathrm{~min}$.

\subsection{Antibacterial Activity}

\subsubsection{Bacteria strains and procedures}

For antimicrobial evaluation 4 strains of ATCC bacteria were used (Bacillus cereus 11778, Staphylococcus aureus 25923, Salmonella tiphymurium 14028 , Escherichia coli 25922), and were elaborated ethanolic extracts from the drug at 30 , 50 and $70 \%$ according of methodology propose by Rogger et al., 1990, and Biavati et al., 2008 with some modifications. The microorganisms were obtained from the Mycological Laboratory, BioCen, Bejucal, Mayabeque province, Cuba. The maximum concentration of the extracts employed to determine the MICs and MBCs was $250 \mathrm{mg} / \mathrm{mL}$ in base of extracts solubility. None antibiotic were used as inhibition positive control for the realized microbiological studies.

The microorganisms were replanted into Brain-heart infusion, incubated at $35 \pm 2{ }^{0} \mathrm{C}$ during $18-24$ hours. The antibacterial activity was also evaluated by the microdilution method (Hanel and Raether, 1988; Espinel-Ingroff, 2001). The bacterial suspensions were adjusted visually to a turbid standard $0.5 \mathrm{McF}$ arland scale with sterile saline to a concentration of 2 $\mathrm{x} 10^{6} \mathrm{CFU} / \mathrm{mL}$. The inoculate were prepared daily and stored at $+4{ }^{\circ} \mathrm{C}$ until use. Dilutions of the inoculate were cultured on solid medium to verify the absence of contamination and to check the validity of the inoculum.

The sensibility test was realized from isolated strains adjusted with PBS up to reach a standard turbidity of 0.5 in McFarland scale, after that were inoculated by diffusion method in Muller-Hinton Agar.To evaluate extracts antibacterial activity, disc diffusion method was carried out using 6mm filter discs (Verpoorte, Beek, Thomassen, Aandewiel, \& Svendsen, 1983). Bacteria were cultured overnight at $37^{\circ} \mathrm{C}$ in Tryptic Soy Broth (TSB) medium and then adjusted with sterile saline to a concentration of $1.0 \times 10^{5} \mathrm{CFU} / \mathrm{mL}$. The suspension was added to the top of the agar plates in Petri dishes (300 $\mu \mathrm{L} / \mathrm{agar}$ plate) with Mueller-Hinton agar and suspended. Filter discs with extracts $(10 \mu \mathrm{L} / \mathrm{disc})$ were placed on agar plates. After 24 $\mathrm{h}$ of incubation at $37^{\circ} \mathrm{C}$ the diameter of the growth inhibition zones was measured (Sokovic, Glamoclija, Marin, Brkic, \& Griensven, 2010).

\subsubsection{Statistical analysis}

Three specimens were used and all the assays were carried out in triplicate. The results are expressed as mean values and standard deviation (SD). The results were analyzed using one-way analysis of variance (ANOVA) followed by Tukey's HSD Test with $\alpha=0.05$. This treatment was carried out using SPSS v. 18.0 program.

\section{RESULTS AND DISCUSSION}

\subsection{Macroscopical and Microscopical Identification}

The macroscopical morphology evaluation let define that wood is irregular, green-yellowish in color, $60 \mathrm{~cm}$ long and between 8-10 cm wide, characteristic odor and taste lightly astringent (Fig. 2)

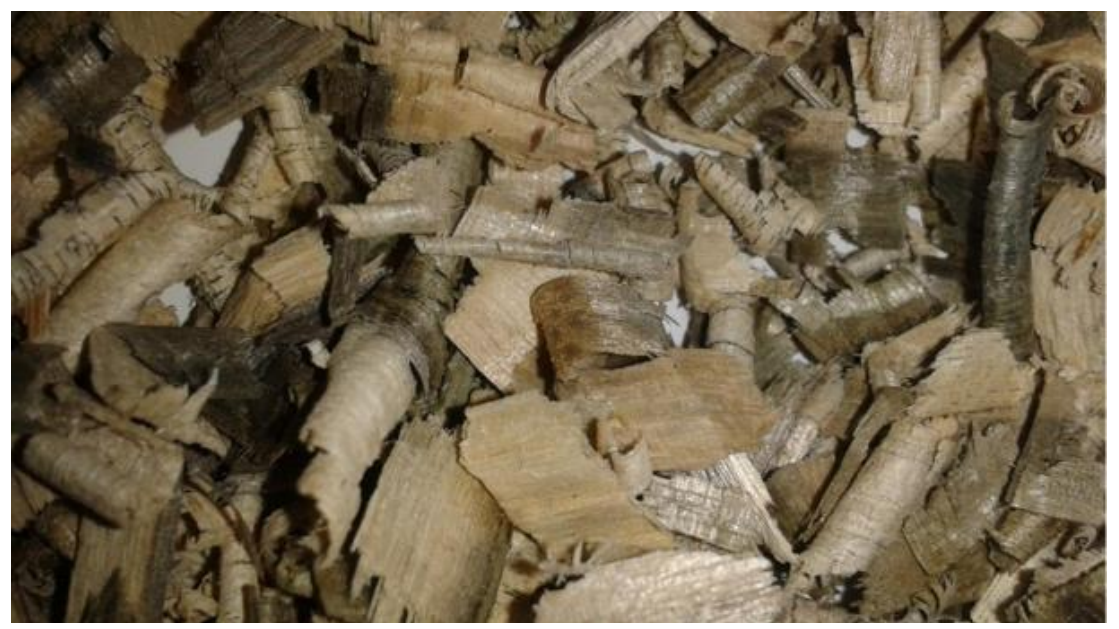

FiG. 2. MACROSCOPICAL CHARACTERISTIC OF WOOD FROM T. ELATUM.

The powdered drug show green color with blue-greenish zones and kept its characteristics odor and taste (Fig. 3). 


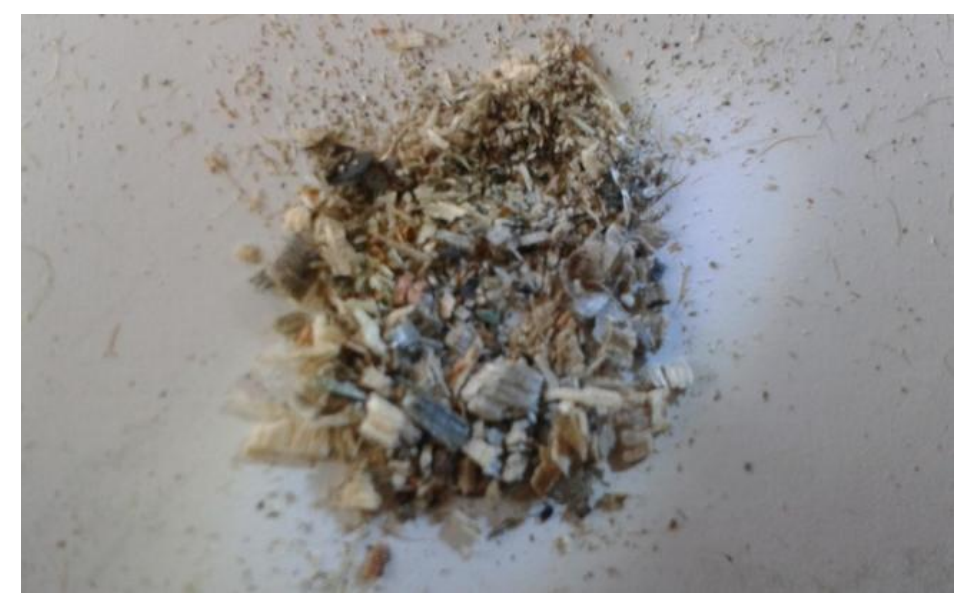

FIG. 3. PULVERIZED DRUG

The micromorphological evaluation of pulverized dry drug showed the presence of fiber with circular and longed cells which seems starch grains inside them with lenticular form (Fig. 4)

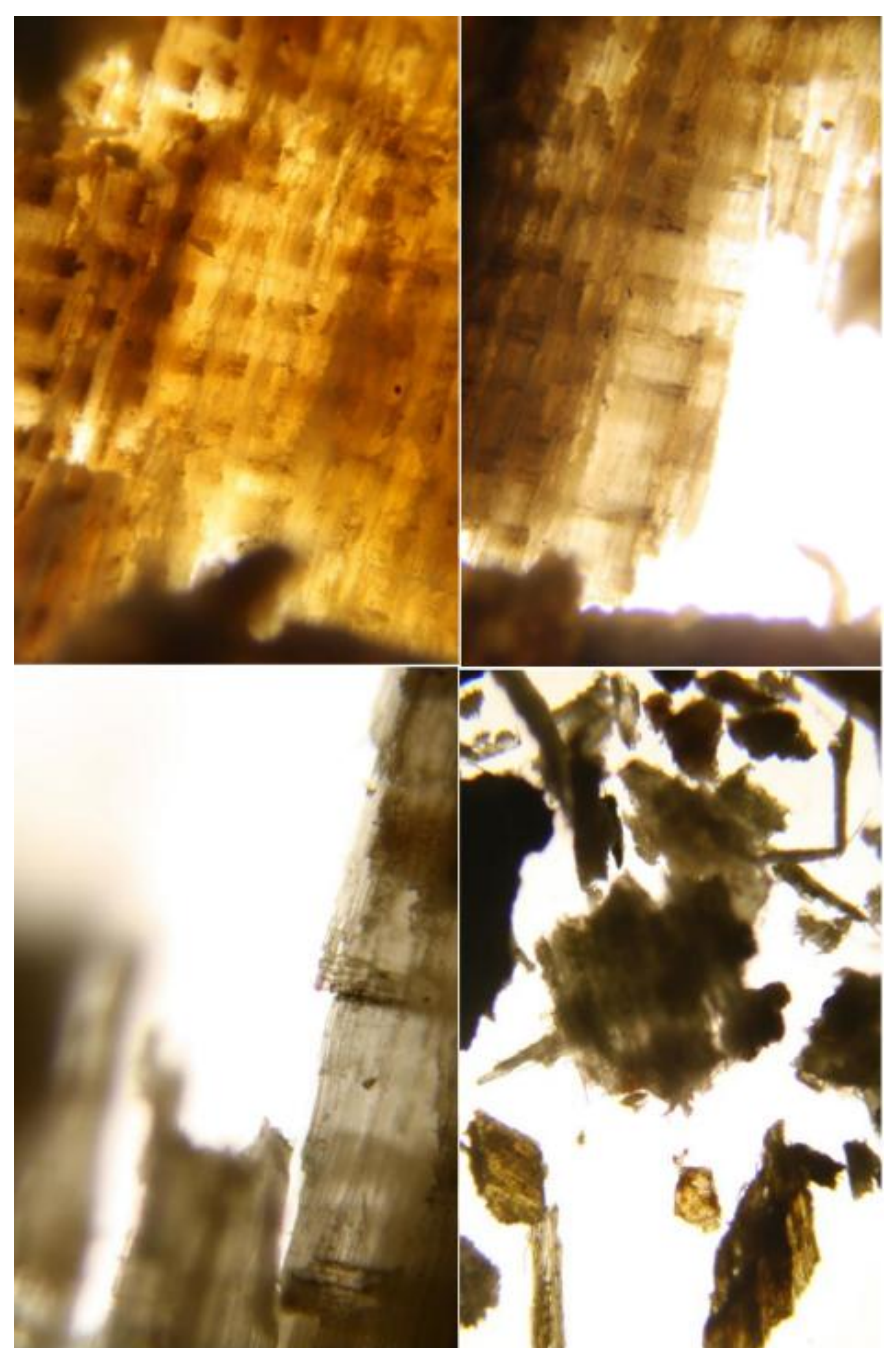

FIG. 4. MICROMORPHOLOGY OF PULVERIZED DRUG

\subsection{Physicochemical Studies}

\subsubsection{Phytochemical Screening}

Preliminary phytochemical screening showed the presence of at least 4 different chemical components in the extracts of the wood (Table 1). Phytochemical examination of the ethanolic extracts indicates the presence of tannins and/or phenolic 
compounds, flavonoids, reductants sugars and triterpenes and steroids. Is obvious, at least preliminary, the absent of the rest of tested chemical compounds. A detailed information will be useful for the development of standardization parameters, isolation of phytoconstituents, screening of preclinical and clinical investigation, manufacturing of formulations and also distinguishing it from its closely related species.

TABLe 1

PHYTOCHEMICAL ANALYSIS OF WOOD OF T. ELATUM (SW.)

\begin{tabular}{|c|c|c|c|}
\hline Test for constituent groups & Diethyl ether & Ethanol & Water \\
\hline Dragendorf & - & - & - \\
\hline Liebermann-Burchard & + & ++ & \\
\hline Börntrager & - & - & \\
\hline Baljet & - & - & \\
\hline Sudan III & - & & ++ \\
\hline Fehling & & + & - \\
\hline Shinoda & & - & + \\
\hline Kedde & & - & \\
\hline FeCl & & - & - \\
\hline Ninhydrin & & - & Lightly astring. \\
\hline Foam & & & + \\
\hline
\end{tabular}

\subsubsection{Physicochemical Characteristics}

The macroscopic and microscopic characters of any plant drug are considered to be the preliminary steps for establishing their quality control profile. As per the guidelines of WHO, pharmacognostical standards should be proposed as a protocol for the diagnosis and authentication of the herbal drugs (Pramanick, 2016).

An excess of water in medicinal plant materials will encourage microbial growth, the presence of fungi or insects, and deterioration following hydrolysis. Limits for water content should therefore be set for every given plant material. This is especially important for materials that absorb moisture easily or deteriorate quickly in the presence of water. Moisture content $(7.6 \%)$ was less than the limited index (8-14\%), indicating that the used dried method was highly efficient. Total ash $(1.14 \%)$, soluble ash in water $(0.19 \%)$ and acid insoluble ash $(0.33 \%)$ wereall lowerthan the official index accepted by the rules of WHO in 1998, which establishes that medicinal drugs must have those parameters around 3-5\% for total ash and less than $2 \%$ for water soluble ash and acid insoluble ash, respectively. The value of extractable matter in ethanol was 10.87 \%indicating that it is an appropriated solvent to realize the extraction of chemical constituents in this part of the plant.

\subsubsection{Chromatographic analysis (TLC)}

Chromatoplates analysis at ordinary light showed the presence of two spots yellow cream, the most closed to solvent front with an $\mathrm{Rf}$ of 0.90 and the second one 0.82 . Long tile appear below but clearer ad a value of Rf of 0.75 almost at the same level of the spot that representing rutin as standard. Chromogenic reveal under $\mathrm{UV}_{365 \mathrm{~nm}}$, showed that chromatoplates change in color, turning to purple, central spot darker. At $U_{254 \mathrm{~nm}}$ the spots turn into bright blue, but central spot with high intensity.

Under ammoniac vapors all spots increased their color. Reveal with $\mathrm{H}_{2} \mathrm{SO}_{4}$ and heat the three same spots were observed again, darker both spots situated below the spot that appear near the solvent front. Chromogenic reveal with $\mathrm{FeCl}_{3}$ showed that the spots were almost invisible, but the spot near solvent front acquired a greenish color indicating the presence of phenolic compounds relating with catecol.

Using $\mathrm{AlCl}_{3}$ yellow color increased in spot situated below of the spot situated below solvent front could be related with chemical compounds like flavonoids. A change of color took place under $\mathrm{UV}_{365 \mathrm{~nm}}$ to dark purple and to bright purple underUV 254 nm (Fig. 5). 


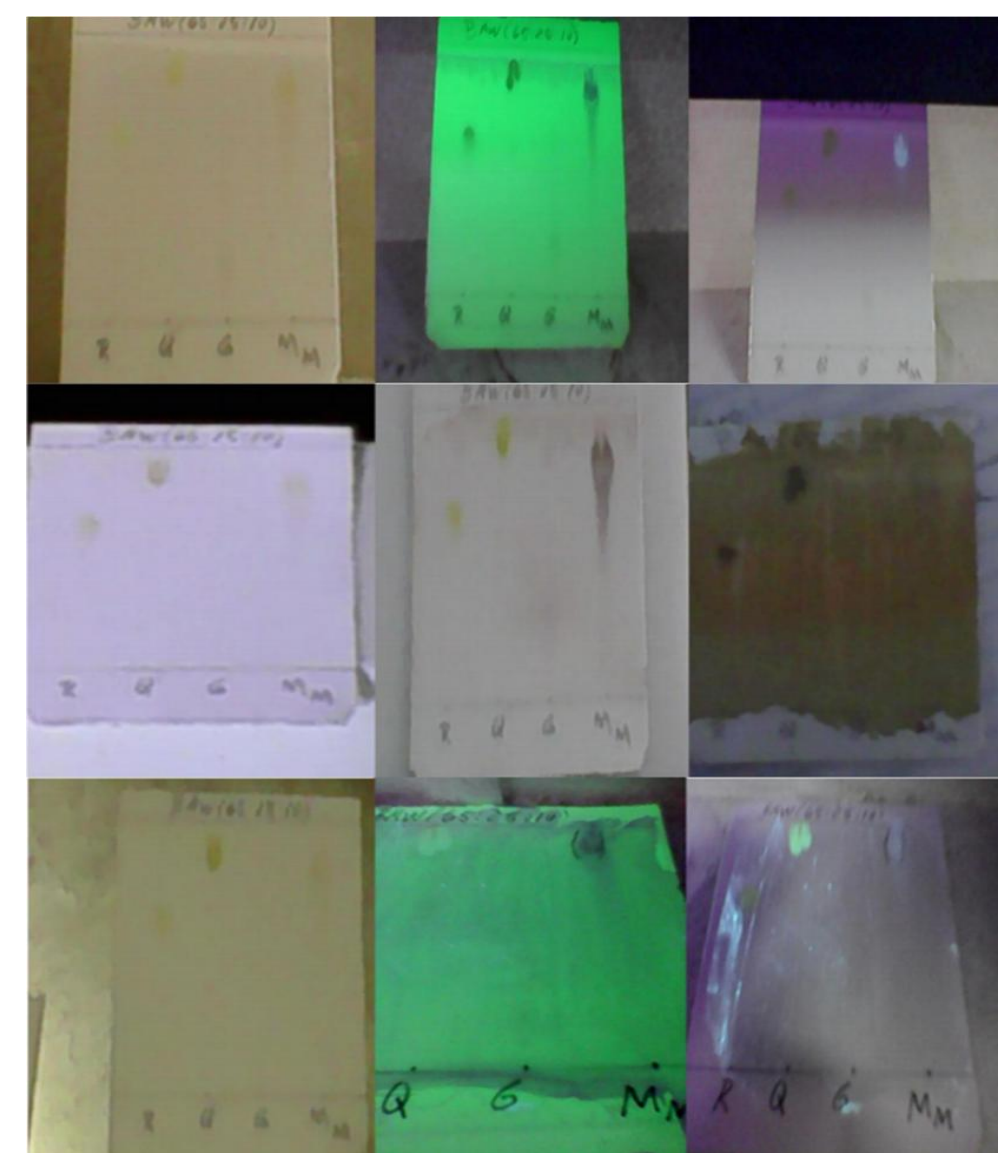

FIG. 5. CCD OF ETHANOLIC EXTRACT AT 70 \% OF WOOD FROM T. ELATUM.

(Legend:Top left-ordinary light; top center-under $U V_{365} \mathrm{~nm}$; top right-under $U V_{254} \mathrm{~nm}$.

Center left-under ammoniac vapors; center middle-reveal with $\mathrm{H}_{2} \mathrm{SO}_{4}$; center left-reveal with $\mathrm{FeCl}_{3}$. Bottom left-reveal with $\mathrm{AlCl}_{3} ; \mathrm{AlCl}_{3}$ under $\mathrm{UV}_{365} \mathrm{~nm} ; \mathrm{AlCl}_{3}$ under $\mathrm{UV}_{365} \mathrm{~nm}$ ).

\subsubsection{Chromatographic profile by HPLC}

HPLC of ethanolic extract at $70 \%$ of wood registered the presence of 44chromatographic peaks which is indicative that a great presence of chemical components into the extract, with retention times between 2.600 up to $48.250 \mathrm{~min}$. The most important peaks belongs to compound 43 (45. $933 \mathrm{~min}$ ) and 44 (48. $250 \mathrm{~min})$, respectively (Fig. 6).

This solvent system showed good resolution of peaks within specific time and was finally selected as mobile phase system for analysis. The results allow infers that until now, the chemical constituents in this plant are included in the range of medium and high polarity.

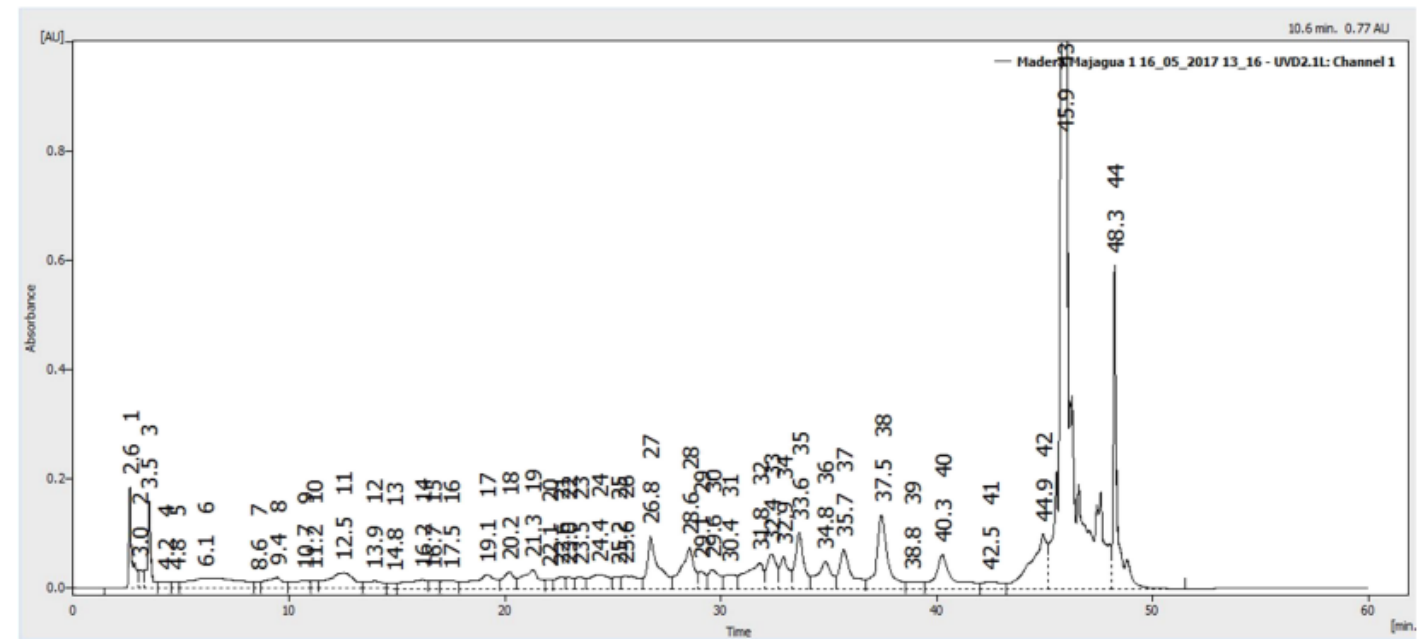

FIG. 6. CHROMATOGRAPHIC PROFILE OF ETHANOLIC EXTRACT AT $70 \%$ OF WOOD FROM T. ELATUM. 


\subsubsection{Antibacterial activity}

\subsubsection{Determination of microbial charge using dilution method and deep culture}

After microorganism accounting (36-72 h) was done the calculation of $\mathrm{CFU} / \mathrm{mL}$. The most interesting result was found in the plates at $10^{-6}$ and $10^{-7}$ with more than 300 colonies (3 $000000 \mathrm{CFU} / \mathrm{mL}$ ), respectively (Fig. 7).

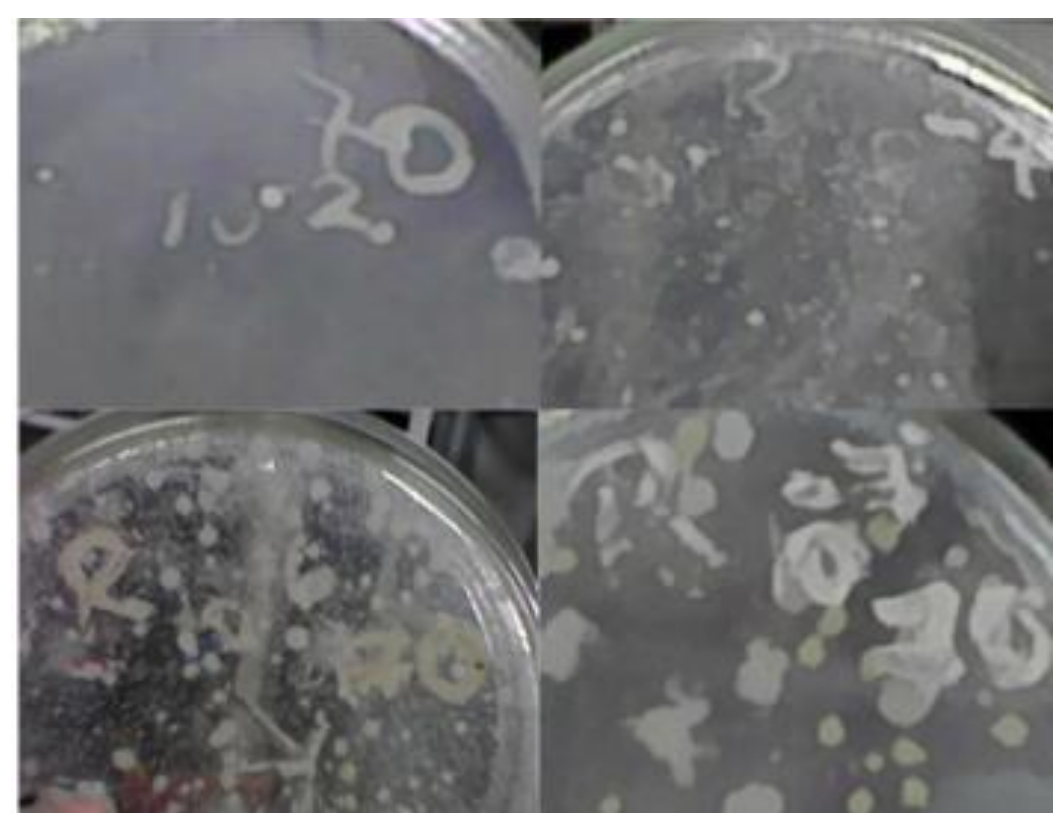

FIG. 7. CFU IN EXTRACT AT $70 \%$ AFTER 24 HOURS

\subsubsection{Colony selection to Gram tinction}

After observation of microbial growth the selected plate was at $10^{-3}$ and we decided to isolate such colonies (the best and more defined). This isolation was done using the method of replanting by puncture $\left(10^{-3}\right)$ or streak $\left(10^{-5}\right)$ to observe the growing and procedure to realize the Gram tinction to define the morphology and cultural characteristics of microorganisms. Tinction were done by duplicate in both cases. Results are expressed in Table 2 and Figure 8.

TABLE 2

RESULTS OF COLONY SELECTION, CHARACTERISTICS AND GRAM TINCTION

\begin{tabular}{|c|c|c|c|}
\hline Plates & Extract at $30 \%$ & Extract at $50 \%$ & Extract at $70 \%$ \\
\hline $10^{-2}$ & & & $\begin{array}{c}\text { Irregular, plane, undefined, white } \\
\text { color } \\
\text { Bacillus Gram + }\end{array}$ \\
\hline $10^{-3}$ & $\begin{array}{c}\text { Circular, plane, entire, yellow color } \\
\text { Tetracoccus Gram }+\end{array}$ & & \\
\hline $10^{-4}$ & & $\begin{array}{c}\text { Irregular, plane, undefined, white } \\
\text { color } \\
\text { Bacillus Gram + }\end{array}$ & $\begin{array}{c}\text { Circular, plane, entire, withe color } \\
\text { Bacillus Gram + }\end{array}$ \\
\hline $10^{-5}$ & $\begin{array}{l}\text { Circular, plane, entire, white color } \\
\text { Staphylococcus Gram + }\end{array}$ & $\begin{array}{l}\text { Irregular, plane, undefined, pale } \\
\text { white color } \\
\text { Bacillus Gram + }\end{array}$ & \\
\hline $10^{-6}$ & & $\begin{array}{c}\text { Irregular, plane, undefined, pale } \\
\text { white color } \\
\text { Bacillus Gram + } \\
\end{array}$ & $\begin{array}{l}\text { Irregular, plane, undefined, withe } \\
\text { color } \\
\text { Bacillus Gram + }\end{array}$ \\
\hline $10^{-7}$ & & $\begin{array}{c}\text { Irregular, plane, undefined, pale } \\
\text { white color } \\
\text { Staphylococcus } \\
\text { Gram + }\end{array}$ & $\begin{array}{l}\text { Irregular, plane, undefined, withe } \\
\text { and yellow color } \\
\text { Bacillus Gram + }\end{array}$ \\
\hline
\end{tabular}




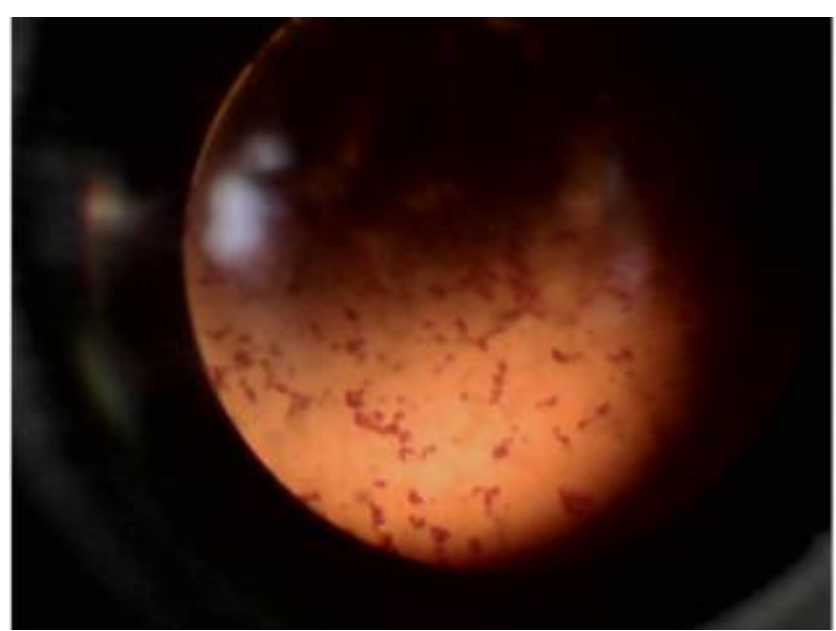

FIG.8. STAPHYLOCOCCUS GRAM +

\subsubsection{Antimicrobial activity of ethanolic extracts}

Extract at $30 \%$ showed before 24 hours in Nutrient Agar solution inhibition zone (50 $\mathrm{mm}$ of diameter) of microorganism in front of Salmonella tiphymurium14028. In Muller-Hinton Agar was observed an inhibition zone of $30 \mathrm{~mm}$ in front of Bacillus cereus 11778 (Fig. 9) using in both cases the disc inoculum at $10^{-3}$.

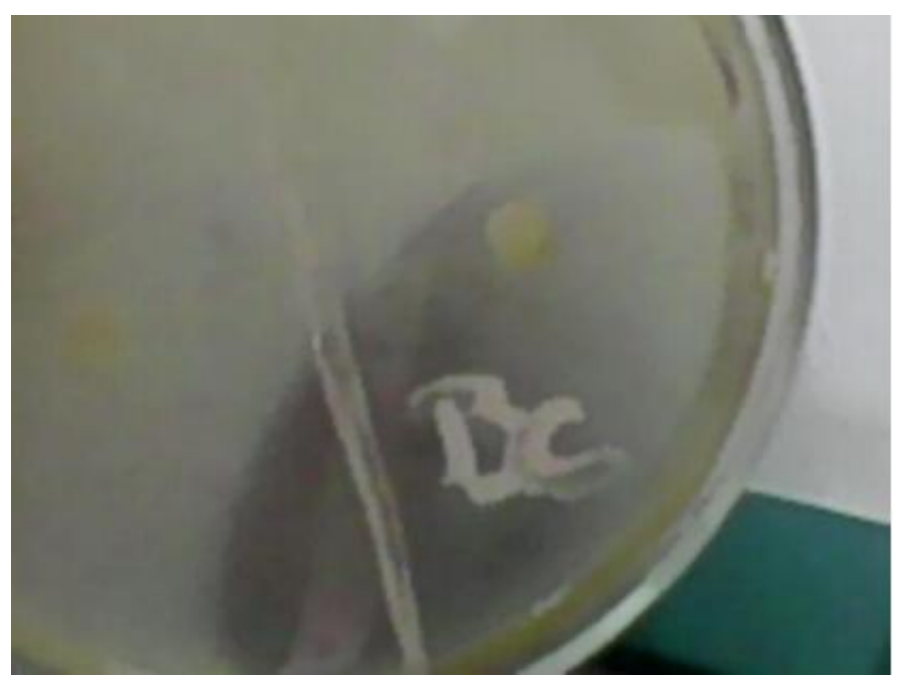

\section{FIG. 9. INHIBITION ZONE IN FRONT OF BACILLUS CEREUS 11778}

Extract sample at $50 \%$ after 24 hours of incubation in Nutrient Agar showed the presence of inhibition zone of $34 \mathrm{~mm}$ in Bacillus cereus 11778 and after 36 hours in Escherichia coli 25922 with the same measure of inhibition zone in inoculated disc at $10^{-1}$ and the full sample, respectively, because we propose that both strains are susceptive (Fig. 10).

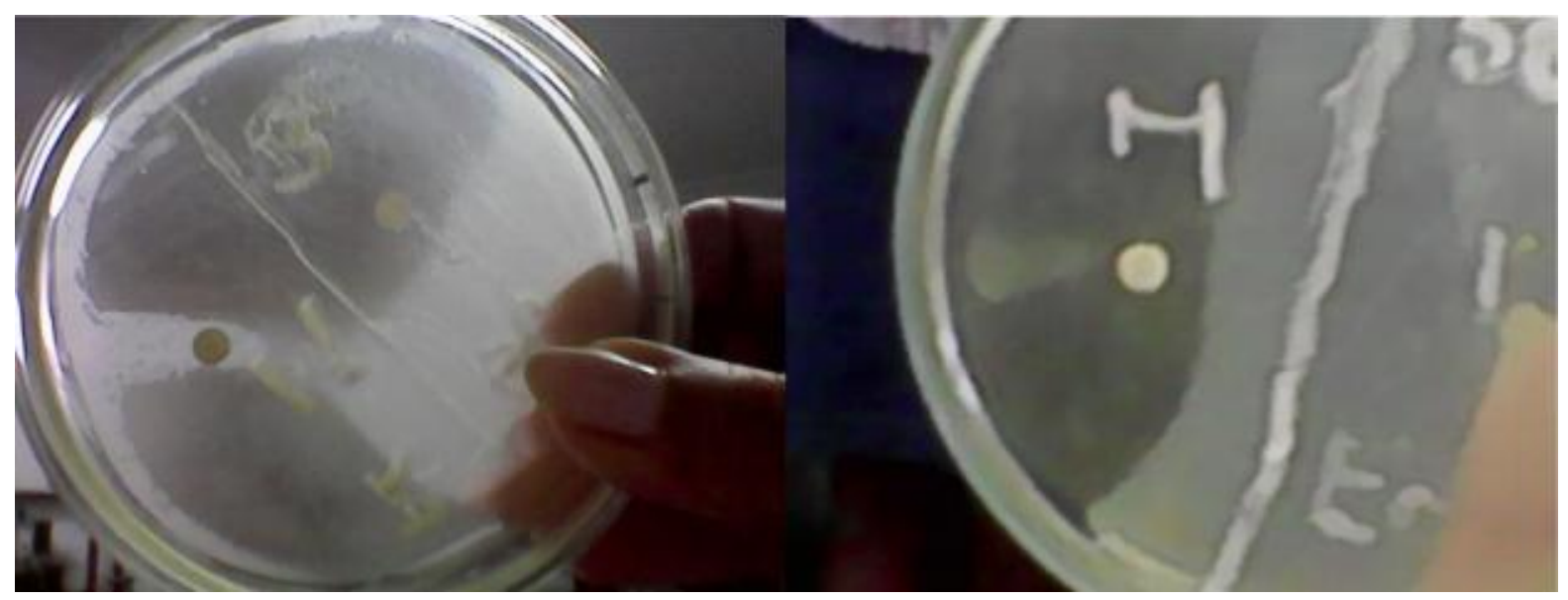

FIG. 10. INHIBITION ZONE FOR BACILLUS CEREUS 11778 AND ESCHERICHIA COLI 25922. 
Finally, ethanolic extract at $70 \%$ after 24 hours in Nutrient Agar showed an inhibition zone of $54 \mathrm{~mm}$ in front of Staphylococcus aureus 25923 in inoculated disc at $10^{-2}$, considering that the strain is susceptible. In the case of inoculated disc with pure sample was observed an inhibition zone of $15 \mathrm{~mm}$ in front of Bacillus cereus 11778, suggesting that this strain of bacteria is medium susceptible or resistant (Fig. 11).

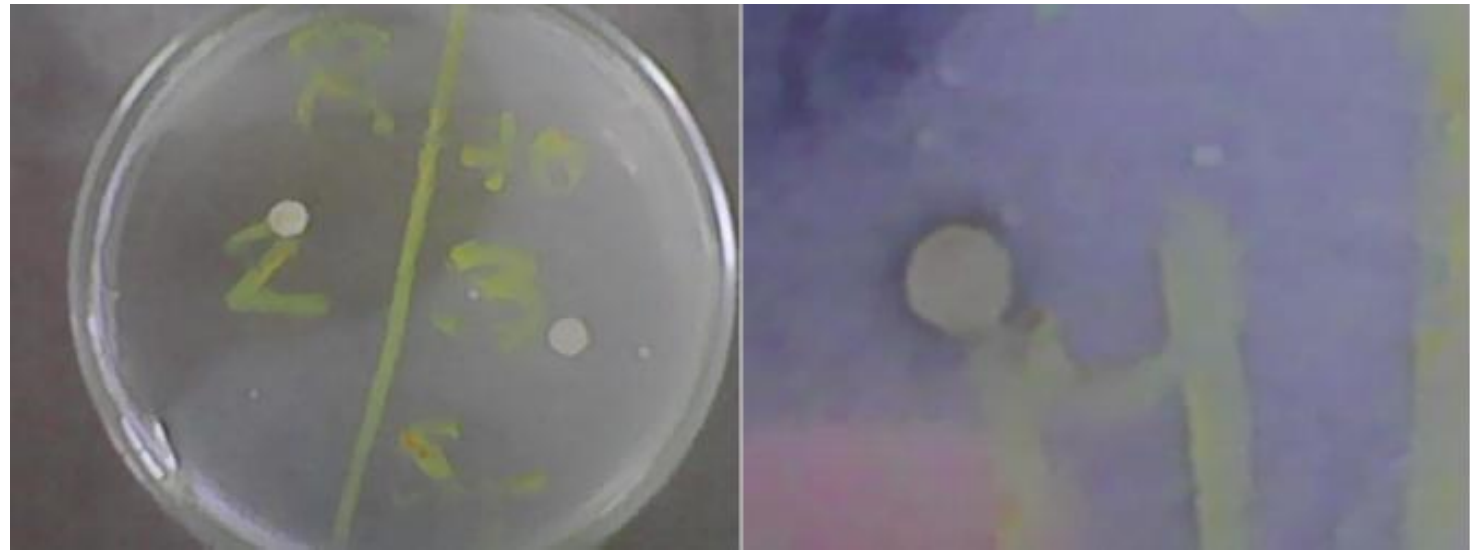

FIG. 11. INHIBITION ZONES IN STAPHYLOCOCCUS AUREUS 25923 AND BACILLUS CEREUS 11778.

In Muller-Hinton Agar was observed an inhibition zone of $18 \mathrm{~mm}$ in front of Staphylococcus aureus 25923 and $16 \mathrm{~mm}$ in front of Bacillus cereus 11778 using pure sample, suggesting that both strains are medium susceptible or resistant (Fig. 12).

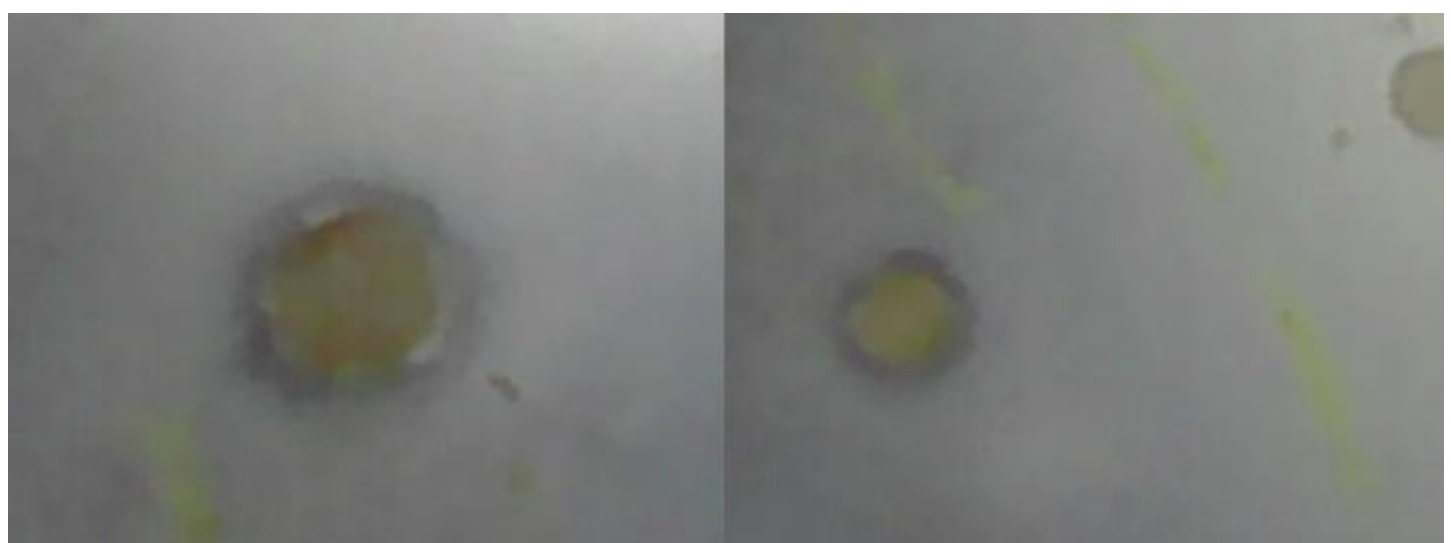

FIG. 12. INHIBITION ZONES IN STAPHYLOCOCCUS AUREUS 25923 AND BACILLUS CEREUS 11778.

\section{Conclusion}

Physicochemical values are all according with the parameters established by the WHO being in all cases below the describe values for vegetable drug, suggesting that the wood of Talipariti elatum(Sw.) can be used to elaborate a phytomedication without the risk of suffer any inconvenient for our health. The chemical compounds present in the ethanolic extracts lead to think that they are chemical metabolites useful to improve medical conditions related with oxidative stress and antidiarrheal illness. Chromatographic profile showed the high presence of chemical constituents in elaborated extracts with ethanol at 70 $\%$. The analyzed ethanolic extracts at 50 and $70 \%$ suggested that CFU belongs to Tetracoccus and Staphylococcus Gram + and Streptobacillus Gram +. Extracts at 30, 50 and $70 \%$ showed antibacterial activity in front of four strains used in the research (Salmonella tiphymurium 14028, Bacillus cereus 11778, Escherichia coli 25922 y Staphylococcus aureus 25923) indicating good possibilities to use those extracts to combat bacterial infections in humans and animals.

Efforts have been made by the authors to bring out every detail on the macroscopical characters of the leaves of this medicinal plant. The study of pharmacognostical features had shown the standards, which will be useful for the detection of its identity and authenticity. It provides reference basis for formulating quality standard of T. elatumauthenticity of medicinal plants and resource utilization.

\section{ACKNOWLEDGEMENTS}

This work was technically supported by the Laboratory of Microbiology, Department of Foods, at Faculty of Pharmacy and Foods, Havana University, Cuba. 
The authors would like to thank Histology Department from Center of Natural Products (National Center of Scientific Researches) for supporting to bring out every detail on the microscopical characters of T. elatum. We extend our sincere thanks to MEDSOL Laboratory for their help in the acquisition of chromatographic profile using HPLC.

\section{CONFLICT OF INTEREST STATEMENT}

We declare that we have no conflict of interest.

\section{REFERENCES}

[1] Acevedo- Rodríguez P and Strong MT. (2013). Catalogue of Seed Plants of the West Indies. Smithsonian Contributions to Botany, number 98. p. 507-508.

[2] Areces F y Fryxell PA. (2007). Flora de la República de Cuba. Fascículo 13. Malvaceae. p. 5-6.

[3] Chhabra, Sc., Uiso, F.C. and Mshin, E.N. (1989). Phytochemical Screening of Tanzanian Medical Plants. I. Journal of Ethnopharmacology, 11, 157-179.

[4] Espinel-Ingroff, A. (2001). Comparation of the E-test with the NCCLS M38-P method for antifungal susceptibility testing of common and emerging pathogenic filamentous fungi. Journal of Clinical Microbiology, 39, 1360-1367.

[5] Fryxell, P. A. (2001). Talipariti (Malvaceae), a segregate from Hibiscus.-Contr. Univ. Michigan Herb. 23: 225-270.

[6] Germplasm Resources Information Network. (2009). United States Department of Agriculture."Talipariti elatum". Retrieved 2009-0127.

[7] Hanel, H., \& Raether, W. (1988). A more sophisticated method of determining the ofwater-insoluble preparations with a cell harvester, using miconazole as an example. Mycoses, 31, 148-154.

[8] Sokovic, M., Glamoclija, J., Marin, P. D., Brkic, D., \& van Griensven, L. J. (2010). Antibacterial effects of the essential oils of commonly consumed medicinal herbs using an in vitro model. Molecules, 15, 7532-7546.

[9] Tropic Ventures Rainforest Enrichment and Sustainable Forestry Project. (2009). "Eye on the Forest".Retrieved 2009-01-27.

[10] Tropicos.org. Missouri Botanical Garden. (2013)."Talipariti elatum (Sw.) Fryxell".Retrieved 6 September 2013.

[11] U. S. Department of Agriculture. (2013). Hibiscus elatus Sw. "mahoe". Natural Resources Conservation Service. Plants Database. Retrieved 6 September 2013.

[12] WHO (1998). Quality Control Methods for Medicinal Plant Materials. Typeset in Hong Kong Printed in England 95/10628Bestset/Clays-6000. 